\title{
NUTRITIONAL STATUS OF ADOLESCENT GIRLS IN SLUMS OF DIBRUGARH TOWN- A CROSS SECTIONAL STUDY
}

\author{
Manjit Boruah ${ }^{1}$, Rashmi Ahmed ${ }^{2}$, Rahul Sarmah ${ }^{3}$ \\ 1 Demonstrator, Department of Community Medicine, Assam Medical College, Dibrugarh. \\ ${ }^{2}$ Assistant Professor, Department of Community Medicine, Assam Medical College, Dibrugarh. \\ ${ }^{3}$ Postgraduate Student, Department of Community Medicine, Assam Medical College, Dibrugarh.
}

\section{ABSTRACT}

\section{BACKGROUND}

Adolescence is the important period of life when $35 \%$ of adult weight and $11-18 \%$ of adult height is acquired. But Adolescent girls (AGs) are particularly at high risk of malnutrition because of gender discrimination in distribution of, and access to, food within the family.

Objective- To assess the prevalence of stunting and thinness among AGs in slums of Dibrugarh district of Assam and the factors influencing.

\section{MATERIALS AND METHODS}

A community-based cross-sectional study was conducted in slums of Dibrugarh town of Assam among AGs between 10-19 years. Sample size was calculated to be 135. Two stage sampling was carried out. Firstly, out of 10 registered slums, 5 were selected randomly. Sample was divided proportionately between the 5 slums based on population. In second stage, AGs from each slum were selected by consecutive sampling. Nutritional status was determined using BMI and Height for age using WHO standard.

\section{RESULTS}

Prevalence of thinness among AGs was $28.89 \%$ and stunting $42.2 \%$. Thinness was found to be significantly associated with educational qualification of father $(p=0.045)$ and educational qualification of mother of $A G(p=0.006)$.

\section{CONCLUSION}

Thinness and stunting among AGs in slums of Dibrugarh town was $28.89 \%$ and $42.2 \%$ respectively.

\section{KEYWORDS}

Adolescent Girls, Slum, Nutritional Status, Stunting, BMI, Thinness.

HOW TO CITE THIS ARTICLE: Boruah M, Ahmed R, Sarmah R. Nutritional status of adolescent girls in slums of Dibrugarh town- A cross sectional study. J. Evolution Med. Dent. Sci. 2017;6(57):4227-4229, DOI: 10.14260/Jemds/2017/917

\section{BACKGROUND}

The entire period of transition from childhood to adulthood is considered as adolescence. WHO defines adolescence in terms of age as spanning the ages between 10 and 19 years ${ }^{1}$ It is the period when $35 \%$ of the adult weight and $11-18 \%$ of the adult height is acquired. ${ }^{2}$ Adolescent age group comprises $20.5 \%$ of the total population in India of which adolescent girls constitute $9.9 \%$. Adolescence is considered as a nutritionally critical period of life as nutritional requirements increases due to growth spurt and there are changes in lifestyle and food habits. ${ }^{3}$ Adolescent girls are particularly at high risk of malnutrition because of gender discrimination in distribution of, and access to, food within the family. Gender discrimination plays an important role in intra household food allocation. ${ }^{3}$ In India, adolescent girls are the most malnourished among women of childbearing age, and over time this has remained unchanged. Childbearing begins by the age of 19 for more than a third of women, contributing to poor maternal nutritional status and birth outcomes. ${ }^{4}$

Financial or Other, Competing Interest: None.

Submission 12-06-2017, Peer Review 06-07-2017,

Acceptance 12-07-2017, Published 17-07-2017.

Corresponding Author:

Dr. Manjit Boruah,

Demonstrator,

Department of Community Medicine,

Assam Medical College, Dibrugarh-786002.

E-mail: drmanjitboruah@gmail.com

DOI: $10.14260 /$ jemds $/ 2017 / 917$
The world's population is increasingly concentrated in urban settlements, presenting both opportunities for and challenges to sustainable development. ${ }^{5}$ Rapid urban growth has led to an increase in the number of urban poor, especially those living in slums. India's urban poor have even outnumbered the rural poor, since 1998. Although urban India has a relatively strong health and nutrition infrastructure - with public sector investments coming from central, state, and local bodies as well as a vast private sector - there is marked inequitable distribution of service availability and utilisation between the rich and poor, between the settled urban population and the marginalised slum dwellers. Vulnerable urban communities continue to be poorly served. This is not only the result of under provision or "service" barriers but is a product of interrelated variables such as poverty, inequitable distribution of primary healthcare services, poor referral systems, vertical programming, and attitudinal and management challenges. ${ }^{6}$

Adolescent girls in slums are a vulnerable group. They are the future mothers and their nutritional status determines their health status in the next stage of their lives. Upper Assam which includes Dibrugarh also has the highest maternal mortality ratio in India- 404 for 1 lakh live births. ${ }^{7}$

So, this study was conducted to assess the nutritional status of adolescent girls in slums of Dibrugarh district of Assam and determine the factors influencing their nutritional status. 


\section{MATERIALS AND METHODS}

A community-based cross-sectional study was conducted in slums of Dibrugarh town of Assam among adolescent girls in the age group of 10-19 years for a period of 6 months from June to November 2016. The sample size was calculated to be 135 by using the formula, $\mathrm{n}=\mathrm{Z}^{2} \mathrm{PQ} / \mathrm{d}^{2}$ considering prevalence of thinness (P) as 31.33\%\% among adolescent girls in urban slums of Dibrugarh ${ }^{8}$ and taking $8 \%$ absolute error $(\mathrm{d}), \mathrm{Q}=\mathrm{P}-1$ and $\mathrm{Z}=1.96$ for $95 \%$ confidence interval.

There are a total of 10 registered slums in Dibrugarh town and 5 slums were chosen randomly for the study using random number table. From each slum 27 adolescent girls were included. The first household in each slum was selected randomly as per method described for Expanded Programme of Immunization (EPI) by $\mathrm{WHO}^{9}$ and then subsequent households were visited consecutively. Households where adolescent girls were present were included in the study.

In each household, the adolescent girl was carefully briefed regarding the purpose of the study. Written informed consent was obtained from all 18-19 years old adolescent girls. For 10-17 years adolescent girls, assent was obtained from the adolescent girl and written informed consent from their legal guardian prior to the interview.

Nutritional status of adolescent girls was determined based on anthropometric measurements. Height was recorded using portable stadiometer up to nearest $0.1 \mathrm{~cm}$ and weight was recorded by electronic weight scale up to $0.10 \mathrm{~kg}$ wearing no shoes, with light clothing. BMI for age and Height for age were then determined using WHO standards. Thinness was defined as BMI for age below -2 SD (Standard deviation) and stunting as height for age below -2 SD. Age of adolescent girls was determined using documentary evidence wherever available.

The study population was described by using percentage, mean and SD. Data was analysed using Chi-square test and Fisher-exact test.

\section{RESULTS}

Out of 135 adolescent girls, majority (74.7\%) were in the age group of 10-14 years. The mean age of the study participants was observed to be $14.05 \pm 2.28$ years. Majority $(93.33 \%)$ of the adolescent girls were literate but $21.48 \%$ were out of school. Most of the adolescent girls belonged to nuclear families (67.6\%). [Table 1].

Overall 39 (28.9\%) adolescent girls in slums of Dibrugarh were thin (including both Thinness and Severe Thinness). However, $96(71.7 \%)$ had normal BMI and no obese or overweight adolescent girls were observed. Overall 57 $(42.2 \%)$ adolescent girls in slums of Dibrugarh were stunted (including both stunted and severe stunted). [Table 2].

The prevalence of overall thinness was higher (71.8\%) in the age group of 10-14 years as compared to the age group of 15-19 years (28.2\%). Also among school going adolescent girls, prevalence of thinness $79.5 \%$ was higher compared to out of school going adolescent girls $20.5 \%$.

Educational qualification of father $(p=0.045)$ and educational qualification of mother of adolescent girl $(p=0.006)$ was found to be significantly associated with thinness in adolescent girls. But other sociodemographic factors were not found to be significantly associated with thinness in adolescent girls.

\begin{tabular}{|c|c|c|c|}
\hline \multirow{2}{*}{\multicolumn{2}{|c|}{$\begin{array}{l}\text { Sociodemographic } \\
\text { Characteristics }\end{array}$}} & \multicolumn{2}{|c|}{$\begin{array}{c}\text { Adolescent } \\
\text { Girls (n=135) }\end{array}$} \\
\hline & & No. & $\%$ \\
\hline \multirow{2}{*}{ Age (years) } & $10-14$ & 100 & 74.07 \\
\hline & $15-19$ & 35 & 25.93 \\
\hline \multirow{4}{*}{$\begin{array}{c}\text { Educational } \\
\text { qualification } \\
\text { (Father) }\end{array}$} & Illiterate & 48 & 35.56 \\
\hline & Below Primary School & 18 & 13.33 \\
\hline & $\begin{array}{c}\text { Primary to Middle } \\
\text { School }\end{array}$ & 33 & 24.44 \\
\hline & High School \& above & 36 & 26.67 \\
\hline \multirow{4}{*}{$\begin{array}{c}\text { Educational } \\
\text { qualification } \\
\text { (Mother) }\end{array}$} & Illiterate & 70 & 51.85 \\
\hline & Below Primary School & 18 & 13.33 \\
\hline & $\begin{array}{l}\text { Primary to Middle } \\
\text { School }\end{array}$ & 29 & 21.48 \\
\hline & High School \& above & 18 & 13.33 \\
\hline \multirow{4}{*}{$\begin{array}{c}\text { Educational } \\
\text { qualification } \\
\text { (Adolescent girls) }\end{array}$} & Illiterate & 9 & 6.67 \\
\hline & Below Primary School & 9 & 6.67 \\
\hline & $\begin{array}{c}\text { Primary to Middle } \\
\text { School }\end{array}$ & 77 & 57.04 \\
\hline & High School \& above & 40 & 29.63 \\
\hline \multirow{2}{*}{ Type of Family } & Nuclear & 90 & 66.67 \\
\hline & Joint & 45 & 33.33 \\
\hline \multirow{5}{*}{$\begin{array}{c}\text { Socioeconomic } \\
\text { Status (B. G. Prasad } \\
\text { Classification) }\end{array}$} & Class I & 1 & 0.74 \\
\hline & Class II & 13 & 9.63 \\
\hline & Class III & 36 & 26.67 \\
\hline & Class IV & 67 & 49.63 \\
\hline & Class V & 18 & 13.33 \\
\hline \multirow{2}{*}{$\begin{array}{c}\text { School Enrolment } \\
\text { status }\end{array}$} & School going & 106 & 78.52 \\
\hline & Out of school & 29 & 21.48 \\
\hline
\end{tabular}

\begin{tabular}{|c|c|c|c|c|}
\hline \multicolumn{3}{|c|}{$\begin{array}{c}\text { Nutritional status of } \\
\text { Adolescent Girls }\end{array}$} & $\begin{array}{c}\text { Number } \\
(\mathbf{n = 1 3 5})\end{array}$ & $\%$ \\
\hline \multirow{4}{*}{$\begin{array}{c}\text { BMI for } \\
\text { age }\end{array}$} & Obesity & $>+2$ SD & 0 & 0 \\
\cline { 2 - 5 } & Overweight & $>+1$ SD to +2 SD & 0 & 0 \\
\cline { 2 - 5 } & Normal & -2 SD to +1 SD & 96 & 71.7 \\
\cline { 2 - 5 } & Thinness & $<-2$ SD to -3 SD & 25 & 18.5 \\
\cline { 2 - 5 } & Severe thinness & $<-3$ SD & 14 & 10.4 \\
\hline \multirow{3}{*}{$\begin{array}{c}\text { Height } \\
\text { for age }\end{array}$} & Normal & $>-2$ SD & 78 & 57.8 \\
\cline { 2 - 5 } & Stunted & $\begin{array}{c}\text { (<-2 SD to -3 } \\
\text { SD) }\end{array}$ & 48 & 35.6 \\
\cline { 2 - 5 } & Severely stunted & (<-3 SD) & 9 & 6.6 \\
\hline \multicolumn{4}{|c|}{ Table 2. Nutritional Status of Adolescent Girls } \\
\hline \multicolumn{4}{|c|}{} & \multicolumn{4}{|c|}{} \\
\hline
\end{tabular}

\begin{tabular}{|c|c|c|c|c|}
\hline \multirow{2}{*}{\multicolumn{2}{|c|}{$\begin{array}{c}\text { Sociodemographic } \\
\text { Characteristic of Adolescent Girls }\end{array}$}} & \multicolumn{2}{|c|}{$\begin{array}{c}\text { Thinness } \\
(n=39)\end{array}$} & \multirow{2}{*}{\begin{tabular}{|c|}
$\mathbf{p}-$ \\
value \\
$*$
\end{tabular}} \\
\hline & & No. & $\%$ & \\
\hline \multirow{2}{*}{ Age (Years) } & $10-14$ & 28 & 71.8 & \multirow{2}{*}{0.700} \\
\hline & $15-19$ & 11 & 28.2 & \\
\hline \multirow{4}{*}{$\begin{array}{c}\text { Educational } \\
\text { qualification } \\
\text { (Father) }\end{array}$} & Illiterate & 10 & 25.6 & \multirow{4}{*}{0.045} \\
\hline & Below Primary School & 2 & 5.1 & \\
\hline & Primary to Middle School & 12 & 30.8 & \\
\hline & High School \& a & 15 & 38.5 & \\
\hline \multirow{4}{*}{$\begin{array}{c}\text { Educational } \\
\text { qualification } \\
\text { (Mother) }\end{array}$} & Illit & 14 & 35.9 & \multirow{4}{*}{0.006} \\
\hline & Below Prima & 3 & 7.7 & \\
\hline & Primary to Middle School & 12 & 30.8 & \\
\hline & High School \& al & 10 & 12.6 & \\
\hline \multirow{4}{*}{$\begin{array}{c}\text { Educational } \\
\text { qualification } \\
\text { (Adolescent } \\
\text { girls) }\end{array}$} & Illitel & 0 & 0.0 & \multirow{4}{*}{0.136} \\
\hline & Below Primary School & 4 & 10.3 & \\
\hline & Primary to Middle School & 21 & 53.8 & \\
\hline & High School \& above & 14 & 35.9 & \\
\hline \multirow{2}{*}{ Type of Family } & Nuclear & 27 & 69.2 & \multirow{2}{*}{0.689} \\
\hline & Joint & 12 & 30.8 & \\
\hline \multirow{2}{*}{$\begin{array}{c}\text { Socioeconomic } \\
\text { Class }\end{array}$} & Class I & 1 & 2.6 & \multirow{2}{*}{0.428} \\
\hline & Class II & 2 & 5.1 & \\
\hline
\end{tabular}




\begin{tabular}{|c|c|c|c|c|}
\hline \multirow{2}{*}{$\begin{array}{c}\text { (B. G. Prasad } \\
\text { Classification) }\end{array}$} & Class III & 10 & 25.6 & \\
\cline { 2 - 4 } & Class IV & 20 & 51.3 & \\
\cline { 2 - 4 } $\begin{array}{c}\text { School } \\
\text { Enrolment } \\
\text { Status }\end{array}$ & Class V & 6 & 15.4 & \\
\cline { 2 - 4 } & School going & 31 & 79.5 & \multirow{2}{*}{0.862} \\
\hline \multicolumn{2}{|c|}{ Ouble 3. Thinness in Adolescent Girls and } \\
Sociodemographic Characteristics \\
\hline
\end{tabular}

[Percentages are calculated column wise] ${ }^{*}$ Chi-Square test

\section{DISCUSSION}

In the present study, the prevalence of thinness among adolescent girls in slums of Dibrugarh was $28.89 \%$. Bhattacharyya $M$ et al reported $30 \%$ prevalence of underweight among adolescent school girls in urban slum of Kolkata. ${ }^{10}$ Baliga et al reported $39.43 \%$ adolescent girls between the age 15 and 19 years were thin from District Belgaum, Karnataka. ${ }^{11}$ Difference in prevalence reported by Baliga et al may be due to non-inclusion of 10-14 years age group of adolescent girls.

In the present study, no adolescent girl was overweight or obese. Kowsalya $\mathrm{T}$ et al observed $6.86 \%$ adolescent girls in Salem District, India were overweight or obese. ${ }^{12}$ Patanwar P et al reported $3.6 \%$ adolescent girls in Raipur city, Chhattisgarh as overweight. ${ }^{13}$ Lower sample size in the present study may have been the cause of this observation.

$42.2 \%$ adolescent girls were stunted in the present study. Rajaretnam $\mathrm{T}$ et al observed $26.5 \%$ stunting among adolescent girls in urban areas of northern Karnataka. ${ }^{14}$ Stunting among adolescent girls in rural areas was reported in the range of $40.84 \%$ to $30.39 \%$ in different parts of India. ${ }^{11,15}$ Higher stunting among adolescent girls observed in slums in Dibrugarh signifies that chronic malnutrition is a major problem here.

In the present study, thinness was found to be significantly associated with educational qualification of parents of adolescent girl but not socioeconomic status. Chaudhary $\mathrm{S}$ et al observed thinness in adolescent girls decreased with increase in literacy status of the family. In the present study, thinness was more in lower socioeconomic class (III-V) than higher (I-II) but the association was not significant. Chaudhary $\mathrm{S}$ et al also made similar observation that undernutrition was significantly less in the subjects belonging to higher socioeconomic class. ${ }^{16}$

\section{CONCLUSION}

Thinness (28.89\%) and stunting (42.2\%) among adolescent girls in slums of Dibrugarh can lead to impaired growth. Education status of parents is significantly associated with thinness in adolescent girls.

\section{REFERENCES}

[1] Adolescent health. http://www.who.int/topics/adolescent_health/en/ 2017.
[2] Sachdev HPS. Chaudhary P. Nutrition in children: developing country concerns. $2^{\text {nd }}$ edn. New Delhi: PBI Publication 1995:272-3.

[3] Adolescent nutrition: a review of the situation in selected South-East Asian countries. WHO, Regional office for SEAR, New Delhi. 2006.

[4] India nutrition profile. https://www.fantaproject.org/sites/default/files/do wnload/India-Nutrition-Profile-Mar2014.pdf 2017.

[5] Population facts 2014. United Nations, Population Division.

http://www.un.org/en/development/desa/populatio n/publications/pdf/popfacts/PopFacts_2014-3.pdf. 2017.

[6] EHP Report on national consultation on improving the health of the urban poor. Bangalore, 2003. Bangalore: Environmental Health Project 2003.

[7] Annual Health Survey 2012-13. Fact sheet Assam. New Delhi, Vital Statistics Division, Office of the Registrar General \& Census Commissioner, India.

[8] Bhattacharyya H, Barua A. Nutritional status and factors affecting nutrition among adolescent girls in urban slums of Dibrugarh, Assam. Natl J Community Med 2013;4(1):35-9.

[9] Training for Mid-level Managers (MLM). Module 7: The EPI coverage survey. CH-1211 Geneva 27, Switzerland: World Health Organization, Department of Immunization, Vaccines and Biologicals, 2008.

[10] Bhattacharyya M, Sen P, Hazra S, et al. Prevalence of overweight and obesity among adolescent school girls in urban slum of Kolkata. IJHSR 2015;5(3):59-65.

[11] Baliga SS, Naik VA, Mallapur MD. Nutritional status of adolescent girls residing in rural area: a communitybased cross-sectional study. Journal of the Scientific Society 2014;41(1):22-5.

[12] Kowsalya T, Parimalavalli R. Prevalence of overweight/obesity among adolescent girls in Salem District, India. Indian Journal of Health Sciences 2014;7(2):73-7.

[13] Patanwar P, Sharma KKN. Nutritional status of Kurmi adolescent girls of Raipur city Chhattisgarh, India. International Journal of Scientific and Research Publications 2013;3(11)1-6.

[14] Rajaretnam T, Hallad JS. Nutritional status of adolescents in northern Karnataka, India. The Journal of Family Welfare 2012;58(1):55-67.

[15] Gaiki V, Wagh V. Nutritional status of adolescent girls from selected rural area of a district from Central India. Innovative Journal of Medical and Health Science 2014;4(2):90-2.

[16] Chaudhary S, Mishra C, Shukla K. Correlates of nutritional status of adolescent girls in the rural areas of Varanasi. The Internet Journal of Nutrition And Wellness 2008;7(2)1-10. 